\title{
Delisheng, a Chinese medicinal compound, exerts anti-proliferative and pro-apoptotic effects on HepG2 cells through extrinsic and intrinsic pathways
}

\author{
Chuang-xin Lu $\cdot$ Ke-jun Nan $\cdot$ Yan-li Nie • \\ Ya-nan Hai $\cdot$ Min Jiao
}

Received: 14 July 2009/Accepted: 16 November 2009/Published online: 11 December 2009

(c) The Author(s) 2009. This article is published with open access at Springerlink.com

\begin{abstract}
The anti-proliferative, cytotoxic and apoptogenic activities of delisheng, a Chinese medicinal compound, has been investigated. In this study, the hepatocarcinoma cell line (HepG2) and the liver cell line (L-02) were exposed to delisheng $(6.25,50$ and $100 \mu \mathrm{l} / \mathrm{ml})$. Delisheng suppressed the proliferation and viability of normal liver L-02 cells slightly, but strongly inhibited the proliferation and viability of hepatocarcinoma HepG2 cells. The flow cytometric analysis of HepG2 cells demonstrated that delisheng primarily arrested the HepG2 cells at the G1 phase of the cell cycle. Annexin V-FITC/PI staining corroborates the apoptogenic nature of delisheng on HepG2 cells. The anti-proliferative and pro-apoptotic effect of delisheng in HepG2 cells was associated with changes in the $\mathrm{Bcl}-2 / \mathrm{Bax}$ ratio and the induction of caspase-mediated apoptosis. Upregulation of DR5 expression was observed in HepG2 cells after treatment with delisheng. The findings from the present study suggest that delisheng has selective cytotoxic activities against HepG2 cells. Delisheng triggered time- and dose-dependent apoptosis in HepG2 cells by activating the mitochondriamediated and death receptor-mediated apoptotic pathways.
\end{abstract}

Keywords Delisheng - HepG2 - Caspase - Apoptosis · Bcl-2 - DR5

C. Lu $\cdot$ K. Nan $(\triangle) \cdot$ Y. Nie $\cdot$ Y. Hai $\cdot$ M. Jiao

Cancer Center of The First Affiliated Hospital, College of Medicine of Xi'an, Jiaotong University, 710061 Xi'an, Shanxi Province, China

e-mail:nankj@yahoo.com.cn

\section{Introduction}

Cancer is a complex multifactorial disease of the cell. Transformed cells are not constrained by growth controls, which regulate the proliferation of normal cells. Nowadays, chemotherapy is one of the most important and key tools for cancer treatment. However, the effects of such chemotherapeutic drugs on most solid tumors are disappointing.

Hepatocellular carcinoma (HCC) is a highly malignant tumor with very high morbidity and mortality rates, and a poor prognosis. Despite extensive efforts by many investigators, systemic chemotherapy for HCC has been quite ineffective, as demonstrated by low response rates and no survival benefits [1-4]. In recent years, it has been proven that some traditional Chinese medicines (TCMs) have a marked effect on treating $\mathrm{HCC}$, with unique advantages, and have gained wide acceptance as a safe, palliative and effective treatment in China [5-9]. Delisheng (DLS), a Chinese medicinal compound that is composed of ginseng, milk vetch root, bufonis secretions and cantharidium, is usually used alone or in combination with chemotherapy for HCC and other cancers. Bufonis secretions, such as bufalin, were found to generally inhibit growth of human leukemia cells and were later examined in detail against the liver carcinoma PLC/PRF/5 cell line [10]. Bufalin was also found to inhibit endothelial cell proliferation and angiogenesis and has effects on the proliferation of prostate cancer cells $[11,12]$. In vivo, Bufalin has significant antitumor activities in an orthotopic transplantation tumor model of human hepatocellular carcinoma in nude mice with no marked toxicity and was able to induce apoptosis of transplanted tumor cells [13]. Chinese clinical research reports that DLS injection removes blood stagnation and has the effect of strengthening the body's immunity. When 
used alone, DLS treatment by intravenous dripping for 10 days a month can alleviate specific symptoms such as weakness, improve quality of life, extend life expectancy, and lower prostate specific antigen (PSA) levels in $80 \%$ of the prostate cancer patients [14]. Though DLS is attractive as a natural product for medicinal use, its method of action remains unclear.

Apoptosis, or programmed cell death, is thought to play a key role in the development and regulation of growth of both normal and cancerous cells. Induction of apoptosis has been considered the major cytotoxic mechanism of anticancer therapies. Generally, apoptosis may occur via the mitochondrial (intrinsic) pathway [15] or the death receptor (extrinsic) pathway [16]. In the mitochondrial (intrinsic) pathway, the regulation of apoptosis involves a large set of proteins including $\mathrm{Bcl}-2$, an anti-apoptotic protein [17], which disrupts the mitochondria membrane potential, resulting in release of apoptogenic factors from the mitochondria to the cytoplasm.

To further understand the molecular mechanism of the anti-tumor effects of DLS, we investigated the effects of DLS in human hepatocarcinoma cells and normal liver cells by using HepG2 and L-02 cell lines, respectively. We found that DLS induces apoptosis in HepG2 cells and that both extrinsic and intrinsic signaling pathways contributed to DLS-induced apoptosis.

\section{Materials and methods}

Human cells and culture

Human cancer cells (HepG2) and normal liver cells (L-02) were cultured in RPMI 1640 and DMEM medium, respectively. Both RPMI 1640 and DMEM media were supplemented with $10 \%$ fetal bovine serum (heat inactivated), penicillin (100 units/ml) and streptomycin $(100 \mathrm{mg} / \mathrm{ml})$. Cell lines were maintained in a humidified incubator with $5 \% \mathrm{CO}_{2}$ and $95 \%$ oxygen at $37^{\circ} \mathrm{C}$. Cells were passaged twice a week at an initial density of $1 \times 10^{6}$ cells $/ \mathrm{ml}$.

\section{MTT assay}

MTT assay was done according to Kawada et al. $150 \mu \mathrm{l}$ of HepG2 cells $\left(1 \times 10^{5}\right.$ cells $)$ suspended in RPMI 1640 medium supplemented with $10 \%$ fetal calf serum were added to each well of a 96-well microtiter plate. Cells were cultured in the presence or absence of delisheng $(6.25,25$ and $100 \mu \mathrm{l} / \mathrm{ml})$. Plates were incubated at $37^{\circ}$ in a humidified $5 \% \mathrm{CO}_{2}$ incubator for $48 \mathrm{~h}$. Then, $20 \mu \mathrm{l}$ of MTT $(5 \mathrm{mg} / \mathrm{ml})$ was added to each well and allowed to incubate at $37^{\circ} \mathrm{C}$ in a humidified $5 \% \mathrm{CO}_{2}$ incubator for $4 \mathrm{~h}$. Next, $150 \mu \mathrm{l}$ DMSO was added to each well to dissolve the formazan crystal that formed. The OD was recorded at $490 \mathrm{~nm}$. The rate of growth inhibition (\%) was expressed as $=(1-\mathrm{OD}$ of treated/OD of control $) \times 100 \%$.

Cell cycle analysis

For the analysis of cell cycle phase distribution, respective control and delisheng treated cancer cells $\left(1 \times 10^{6}\right.$ cells per group) were washed with PBS after $24 \mathrm{~h}$ of delisheng $(25 \mu \mathrm{l} / \mathrm{ml})$ and were fixed in $70 \%$ ethanol and stained with $10 \mu \mathrm{l}$ of propidium iodide $(100 \mu \mathrm{g} / \mathrm{ml})$ and $10 \mu \mathrm{l}$ RaseA $(5 \mu \mathrm{g} / \mathrm{ml})$. DNA content of cells was subsequently analyzed by flow cytometry (Becton-Dickinson, USA). Raw data for the distribution of DNA content were expressed as the percentage of $\mathrm{G} 1, \mathrm{~S}$, and $\mathrm{G} 2$ populations.

Annexin V-FITC/PI stained fluorescence-activated cell sorting (FACS)

Cells were harvested by trypsinization and washed twice with cold PBS. The cells were centrifuged at 1,000 rpm for $5 \mathrm{~min}$. The supernatant was discarded and the pellet was resuspended in binding buffer at a density of $1.0 \times 10^{5}$ $1.0 \times 10^{6}$ cells per $\mathrm{ml}$. Then, $100 \mu \mathrm{l}$ of the sample solution was transferred to a $5 \mathrm{ml}$ culture tube, and incubated with 5 ul of FITC-conjugated Annexin V and $5 \mu$ of PI for $15 \mathrm{~min}$ at room temperature in the dark. Next, $400 \mu \mathrm{l}$ of binding buffer was added to each sample. The samples were subsequently analyzed by FACS using Cell Quest Research Software.

Immunocytochemistry staining

Immunocytochemistry was carried out using the SP kit followed by the DAB Substrate Kit for Peroxidase according to manufacturer's instructions. Briefly, the cells were washed with PBS ( $\mathrm{pH} 7.5$ ) and incubated overnight at $4^{\circ} \mathrm{C}$ with the primary antibodies. After washing three times with PBS, the cells were incubated with a secondary antibody for $20 \mathrm{~min}$ at room temperature. After washing three times with PBS, the cells were immunostained with avidinbiotin complex for $30 \mathrm{~min}$. Visualization of the immunoreactions was conducted with $3,3^{\prime}$-diaminobenzidine (DAB, Sigma, UK) for $5 \mathrm{~min}$.

\section{Western blot analysis}

HepG 2 cells were collected by centrifugation at $500 \times \mathrm{g}$ for $5 \mathrm{~min}$, and the pellets were resuspended in lysis buffer (1\% NP40, $1 \mathrm{mM}$ phenylmethylsulfonyl fluoride, $40 \mathrm{mM}$ Tris- $\mathrm{HCl}$ [pH 8.0], $150 \mathrm{mM} \mathrm{NaCl}, 1 \mathrm{mM} \mathrm{NaOH}$ ) at $4^{\circ}$ for $15 \mathrm{~min}$. Cell lysates were fractionated on $12.5 \%$ 
SDS-polyacrylamide gels before being transferred to a nitrocellulose membrane according to standard protocols. Antibody binding was detected by using the enhanced chemiluminescence kit with hyper-ECL film. The antibodies against caspase3, caspase8, caspase9, DR5, Bcl-2, Bax and $\beta$-actin were purchased from Santa Cruz Biotech (Santa Cruz, CA, USA).

Statistical analysis

Values are shown as mean \pm SEM. Statistical analysis was done by Student's $t$ test and one-way ANOVA. $P<0.05$ was considered significant. Statistical calculations were performed by SPSS 13.0.

\section{Results}

Effects of delisheng on the proliferation and viability of HepG2 and L-02 cell lines

Delisheng produced time and dose-dependent inhibition of HepG2 cell growth and viability as compared to untreated control cells $(P<0.05)$. After 72 h of treatment with DLS, the inhibitory ratio was low for treatment with $6.25 \mu \mathrm{l} / \mathrm{ml}$ of DLS. The highest inhibitory ratio was about $87 \%$ for cells treated with $100 \mu \mathrm{l} / \mathrm{ml}$ of DLS. The L-02 cells showed much less sensitivity to delisheng compare with HepG2 cells (Table 1).

\section{Cell cycle analysis}

Flow cytometry data on cell cycle phase distribution revealed that HepG2 cells treated with $25 \mu \mathrm{l} / \mathrm{ml}$ of DLS for 24 h exhibited 63.4, 26.9 and $9.6 \%$ of cells in G1, S and G2 phase of the cell cycle, respectively. Untreated HepG2 cells exhibited 26.9, 57.8 and $15.3 \%$ of cells in G1, S and G2 phase of the cell cycle, respectively (Fig. 1). The DLS (25 $\mu \mathrm{l} / \mathrm{ml})$ treated HepG2 cells showed arrest in the G1 phase of the cell cycle.

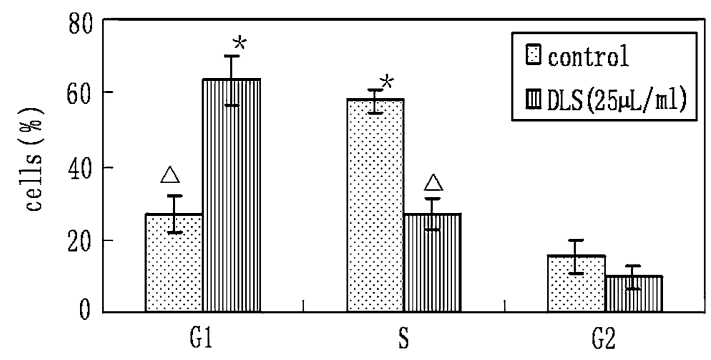

Fig. 1 Effect of delisheng on the cell cycle phase distribution of HepG2 cells. The experiments were repeated four times, the mean percentage cells in G1, S and G2 phases of cell cycle were represented. Error bars represent SEM ( $\triangle$ vs. $\left.{ }^{*} P<0.05\right)$

Annexin V-FITC/PI stained fluorescence-activated cell sorting study

By staining cells with Annexin V-FITC and PI, FACS was used to distinguish and quantitatively determine the percentage of viable and apoptotic cells after treatment with delisheng $(6.25,25,100 \mu \mathrm{l} / \mathrm{ml})$ at $24 \mathrm{~h}$. Delisheng treatment $(6.25,25,100 \mu \mathrm{l} / \mathrm{ml})$ induced apoptosis in 11.44 , 21.86 and $29.67 \%$ of cells, respectively, as evidenced by Annexin V positivity. Only $3.14 \%$ of untreated HepG2 cell were Annexin V positive (Table 2; Fig. 2). Both control and DLS-treated HepG2 cells showed hardly any evidence of necrosis.

DLS triggers caspase-dependent apoptosis pathway in HepG2 cells

To delineate the molecular events initiated by DLS, we first examined the requirement of caspases for the apoptotic program. Exposure of HepG2 cells to DLS resulted in a dose-dependent activation of caspase 3 , caspase 9 and caspase8 (Fig. 3a, b), which indicated the activation of both the intrinsic and extrinsic apoptosis pathways. Moreover, increases in expression levels of death receptor DR5 (Fig. 3b) confirmed the activation of the extrinsic apoptosis pathway. Mitochondria act as a point of integration for apoptotic signals originating from both the extrinsic and intrinsic apoptosis pathways [18]. Bcl-2 family members
Table 1 Growth inhibition effects of delisheng on HepG2 and $\mathrm{L}-02$ cell lines

\begin{tabular}{|c|c|c|c|c|}
\hline \multirow[t]{2}{*}{ Cells } & \multirow[t]{2}{*}{ Concentration $(\mu \mathrm{l} / \mathrm{ml})$} & \multicolumn{3}{|c|}{ Inhibition rate $(\%)$} \\
\hline & & $24 \mathrm{~h}$ & $48 \mathrm{~h}$ & $72 \mathrm{~h}$ \\
\hline \multirow[t]{3}{*}{ HepG2 } & 6.25 & $12.19 \pm 4.25^{\triangle}$ & $23.47 \pm 5.25^{\triangle}$ & $30.96 \pm 7.29^{\triangle}$ \\
\hline & 25.00 & $21.26 \pm 7.06^{\text {斿 }}$ & $38.14 \pm 10.31^{\text {证 }}$ & $49.19 \pm 9.23^{\text {方 }}$ \\
\hline & 100.00 & $55.13 \pm 8.68^{\nabla}$ & $69.64 \pm 9.25^{\nabla}$ & $87.57 \pm 5.66^{\nabla}$ \\
\hline \multirow[t]{3}{*}{ L-02 } & 6.25 & $7.09 \pm 3.47^{\boldsymbol{\Lambda}}$ & $10.13 \pm 4.13^{\boldsymbol{\Lambda}}$ & $11.21 \pm 2.58^{\boldsymbol{\Lambda}}$ \\
\hline & 25.00 & $14.37 \pm 6.21^{\star}$ & $17.68 \pm 8.45^{\star}$ & $18.75 \pm 6.57^{\star}$ \\
\hline & 100.00 & $18.43 \pm 5.32^{\nabla}$ & $19.65 \pm 6.17^{\boldsymbol{\nabla}}$ & $19.03 \pm 4.89^{\boldsymbol{\nabla}}$ \\
\hline
\end{tabular}


Table 2 Apoptosis induction effects of delisheng on HepG2 and L-02 cell lines

^ $\mathrm{vs}^{\nabla} P<0.05$

$\triangle$ Annexin $\mathrm{V}(+) / \mathrm{PI}(-)$ cells

\begin{tabular}{llcrr}
\hline Cells & \multicolumn{4}{l}{ Early apoptisis rate $^{\triangle}(\%)$} \\
\cline { 2 - 5 } & Control & DLS $(6.25 \mu \mathrm{l} / \mathrm{ml})$ & DLS $(25 \mu \mathrm{l} / \mathrm{ml})$ & DLS $(100 \mu 1 / \mathrm{ml})$ \\
\hline HepG2 & $3.14 \pm 0.98$ & $11.44 \pm 3.14^{\star}$ & $21.86 \pm 4.28^{\star}$ & $29.67 \pm 3.01^{\star}$ \\
L-02 & $2.03 \pm 1.01$ & $4.77 \pm 1.25^{\boldsymbol{}}$ & $8.96 \pm 2.21^{\boldsymbol{}}$ & $9.21 \pm 1.98^{\boldsymbol{}}$
\end{tabular}

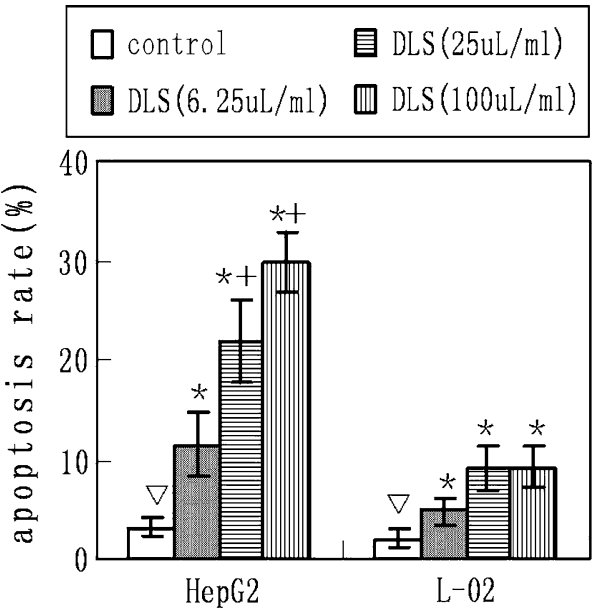

Fig. 2 Effect of DLS on the Annexin V/PI binding of HepG2 and L02 cells. The experiments were repeated four times, the mean percentage of apoptosis cells are represented. Error bars represent SEM ( $\nabla$ vs. $* P<0.05, *$ vs. ${ }^{*} P<0.05$ )

have been described as key regulators of mitochondrial permeability [19]. Therefore, we examined the effects of DLS on the expression levels of Bcl-2 family members in HepG2 cells by western blotting. As shown in Figs. 3a and 4, DLS significantly suppressed the expression level of Bcl2 , and increased the expression level of Bax. These results indicate that mitochondrial-mediated apoptosis in HepG2 cells, triggered by DLS, is predominantly associated with down-regulation of the Bcl-2/Bax expression ratio.

\section{Discussion}

There are many in TCMs that have been used clinically for $>5,000$ years in China and Asia, and increasing attention is being paid to their scientific evaluation. Delisheng is a common Chinese medicinal compound, whose effects have been reported in patients with late-stage HCC. Specifically, DLS has been reported to improve clinical symptoms and quality of life, without severe adverse reactions. However, the mechanisms responsible for these effects are unknown.

It is now well established that the reduced capacity of tumor cells to undergo cell death through apoptosis, plays a key role in both the pathogenesis of cancer and the failure of current therapeutic treatments [20]. In the present study, DLS strongly suppressed the proliferation and viability of

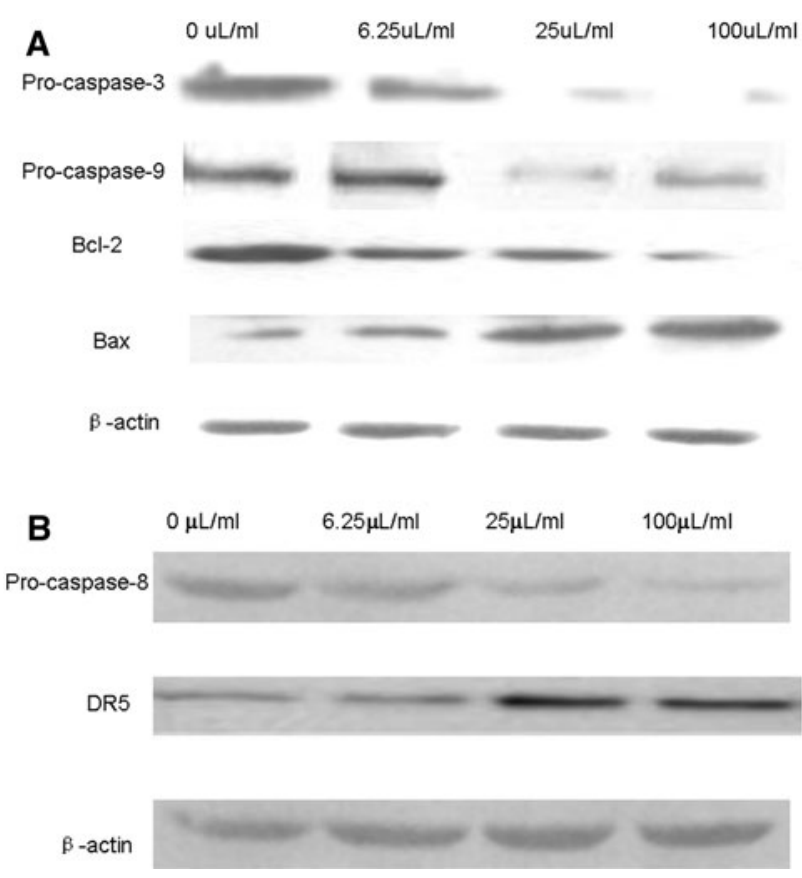

Fig. 3 Western blot analysis of the expression levels of caspase3, caspase9, Bcl-2, Bax, caspase8 and DR5 with the treatment of DLS for $24 \mathrm{~h}$ (All the experiments were repeated four times.)

HepG2 cells, but only slightly inhibited proliferation and viability of L-02 cells. Flow cytometric analysis showed that DLS could induce apoptosis of HepG2 cells. The antiproliferative effect of DLS can be attributed to cell cycle arrest that is induced by the ability of DLS to halt the cell cycle at the G1 phase to prevent further cell proliferation and initiation of apoptotic signaling. DLS can suppress the proliferation and induce apoptosis of HepG2 cells, but has little effect on L-02 cells. This shows that DLS may possess less toxicity for normal liver cells. The fact that DLS has opposite effects on tumor cells and normal cells is intriguing. The results showed that treatment of liver cells with DLS at concentrations $<25 \mu \mathrm{l} / \mathrm{ml}$ is safe, but treatment at a concentration of $100 \mu \mathrm{l} / \mathrm{ml}$ induces the same rate of apoptosis in liver cells as treatments with $25 \mu \mathrm{l} / \mathrm{ml}$ while increases the effectiveness on HepG2 cells largely, which suggests that higher concentrations of DLS can be used when combined with liver protective agents.

Mitochondria act as a point of integration for apoptotic signals because both the intrinsic and extrinsic pathways can converge to trigger mitochondrial membrane 
Fig. 4 Bcl-2, Bax, DR5 protein expression in HepG2 cells $(\times 200)$. a, c, e

Immunocytochemistry of Bcl-2, Bax and DR5 staining in HepG2 cells for $24 \mathrm{~h}$ of treatment without DLS. b, d, f Immunocytochemistry of Bcl-2, Bax and DR5 staining in HepG2 cells for $24 \mathrm{~h}$ of treatment with $25 \mu \mathrm{l} / \mathrm{ml}$ DLS (All the experiments were repeated four times.)

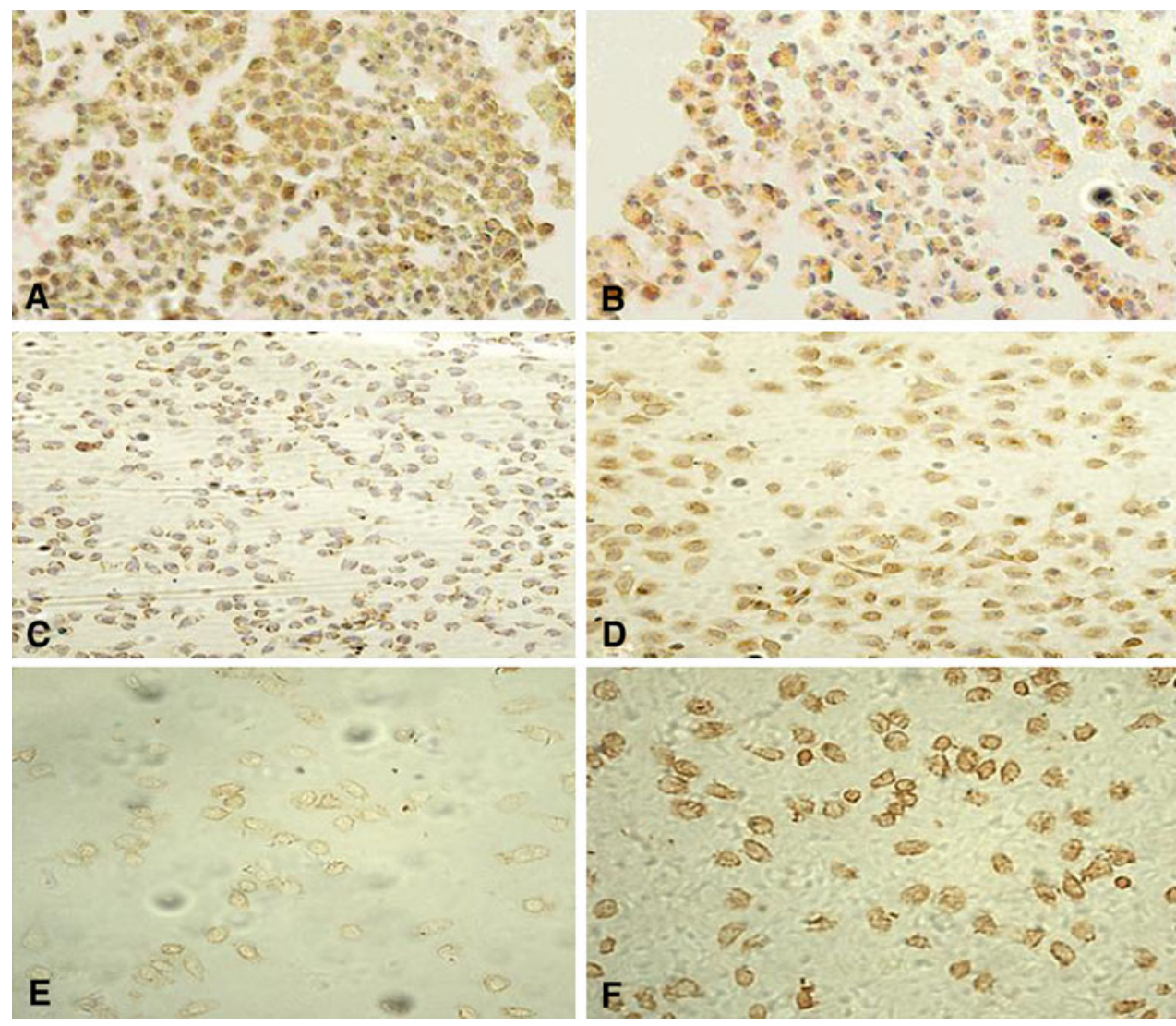

permeabilization [21]. Bcl-2 family proteins that comprise both proapoptotic proteins, such as Bax, Bad and Bid, and antiapoptotic proteins, such as Bcl-2 and Bcl-xL, tightly regulate the mitochondrial apoptosis pathway. Many anticancer drugs trigger mitochondria-mediated apoptosis in cancer cells through downregulation of Bcl-2/Bcl-xL and/ or upregulation of Bax/Bad/Bid. Our results show that DLS treatment significantly downregulates Bcl-2 expression. In our study, the expressions of Bax proteins were enhanced greatly by DLS in a dose-dependent manner. Since Bax has the ability to heterodimerize with the $\mathrm{Bcl}-2$ protein, the ratio of Bcl-2 to Bax appears to be an important marker for the occurrence of apoptosis [22]. A higher Bcl-2/Bax ratio confers a very poor prognosis with decreased rates of complete remission and overall survival [23-26]. Thus, down-regulation of the Bcl-2/Bax expression ratio could be a predominant mechanism by which DLS induces mitochondria-mediated apoptosis in HepG2 cells.

Caspases, a family of cysteine acid proteases, are known to act as important mediators of apoptosis. They are induced by different stimuli and contribute to the overall apoptotic phenotype by cleaving various cellular substrates [27-29]. Tumor necrosis factor (TNF)-related apoptosisinducing ligand (TRAIL), also known as Apo2L, is a cytokine of the TNF family which is capable of inducing apoptotic cell death in a variety of cancer cell types, while having only negligible effects on normal cells [30-32]. DR5 contains a conserved cytoplasmic domain called the 'death domain' that is required for TRAIL-induced apoptosis [33-35]. We found that DLS treatment upregulated the expression of death receptor DR5. Activation of caspase- 8 is required for death receptor-induced apoptosis $[36,37]$.Correspondingly, the reduction of Procaspase 3,8 and 9 in DLS-treated HepG2 cells could indicate that the caspases were activated since the activation of caspase activity results from cleavage of procaspases. For example, activated caspase 8 can cleave and activate effector caspase-3. On the other hand, caspase- 8 can induce Bid cleavage. The cleaved Bid causes the cytochrome c efflux from mitochondria, then activation of caspase 9 and 3 [38]. All of this evidence shows that both the extrinsic and the intrinsic signaling pathways contribute to the DLS-induced apoptosis of HepG2 cells.

In summary, our results suggest that DLS inhibits the growth of HepG2 cells through induction of caspasemediated apoptosis. Both the extrinsic and intrinsic signaling pathways contribute to DLS-induced apoptosis. Further elucidation of the mechanisms involved in the activity of delisheng will help in the development of new approaches to therapy of HCC and other cancers. 
Open Access This article is distributed under the terms of the Creative Commons Attribution Noncommercial License which permits any noncommercial use, distribution, and reproduction in any medium, provided the original author(s) and source are credited.

\section{References}

1. Okuda K (2000) Hepatocellular carcinoma. J Hepatol 32:225-237

2. Rougier P, Mitry E, Barbare JC, Taieb J (2007) Hepatocellular carcinoma (HCC): an update. Semin Oncol 34:S12-S20

3. Llovet JM, Burroughs A, Bruix J (2003) Hepatocellular carcinoma. Lancet 362:1907-1917

4. Llovet JM, Fuster J, Bruix J (2004) The Barcelona approach: diagnosis, staging, and treatment of hepatocellular carcinoma. Liver Transplant 10:S115-S120

5. Rui-Chuan C, Jin-Hua S, Gao-Liang O, Ke-Xia C, Jin-Quan L, Xiao-Guang X (2002) Induction of differentiation in human hepatocarcinoma cells by isoverbascoside. Planta Med 68: 370-372

6. Efferth T, Davey M, Olbrich A, Rucker G, Gebhart E, Davey R (2002) Activity of drugs from traditional Chinese medicine toward sensitive and MDR1- or MRP1-overexpressing multidrug resistant human CCRF-CEM leukemia cells. Blood Cells Mol Dis 28:160-168

7. Mabed M, El-Helw L, Shamaa S (2004) Phase II study of viscum fraxini-2 in patients with advanced hepatocellular carcinoma. Br J Cancer 90:65-69

8. Jang M, Cai L, Udeani GO et al (1997) Cancer chemopreventive activity of resveratrol, a natural product derived from grapes. Science 275:218-220

9. Cheng JT (2000) Drug therapy in Chinese traditional medicine. J Clin Pharmacol 40:445-450

10. Kamano Y, Kotake A, Hashima H et al (1998) Structure-cytotoxic activity relationship for the toad poison bufadienolides. Bioorg Med Chem 6:1103-1115

11. Lee DY, Yasuda M, Yammoto T et al (1997) Bufalin inhibits endothelial cell proliferation and angiogenesis in vitro. Life Sci 60:127-134

12. Yeh JY, Huang WJ, Kan SF et al (2003) Effects of bufalin and cinobufagin on the proliferation of androgen dependent and independent prostate cancer cells. Prostate 54:112-124

13. Han Ke-Qi, Huang G, Gu W, Su Y-H, Huang X-Q, Ling C-Q (2007) Anti-tumour activities and apoptosis-regulated mechanisms of bufalin on the orthotopic transplantation tumour model of human hepatocellular carcinoma in nude mice. World $\mathbf{J}$ Gastroenterol 13:3374-3379

14. Shu-wu Z, Shi-yi Z, Ji-chun S, Xiao-wei Q (2009) Primary research on Chinese medicine treatment of androgen-independent prostate cancer. Chin J Integr Med 15:168-169

15. Li P, Nijhawan D, Budihardjo I, Srinivasula SM, Ahmad M, Alnemri ES, Wang X (1997) Cytochrome c and dATP-dependent formation of Apaf-1/caspase-9 complex initiates an apoptotic protease cascade. Cell 91:479-489

16. Nagata S (1997) Apoptosis by death factor. Cell 88:355-365

17. Luna-More S, Weil B, Bautista D, Garrido E, Florez P, Martinez C (2004) Bcl-2 protein in normal, hyperplastic and neoplastic breast tissues. A metabolite of the putative stem-cell subpopulation of the mammary gland. Histol Histopathol 19:457-463
18. van Gurp M, Festjens N, van Loo G, Saelens X, Vandenabeele P (2003) Mitochondrial intermembrane proteins in cell death. Biochem Biophys Res Commun 304:487-497

19. Cory S, Adams JM (2002) The Bcl2 family: regulators of the cellular life-or-death switch. Nat Rev Cancer 2:647-656

20. Lam MH, Liu Q, Elledge SJ, Rosen JM (2004) Chk1 is haploinsufficient for multiple functions critical to tumor suppression. Cancer Cell 6:45-59

21. Henry-Mowatt J, Dive C, Martinou JC, James D (2004) Role of mitochondrial membrane permeabilization in apoptosis and cancer. Oncogene 23:2850-2860

22. Oltvai ZN, Milliman CL, Korsmeyer SJ (1993) Bcl-2 heterodimerizes in vivo with a conserved homolog, Bax, that accelerates programmed cell death. Cell 74:609-619

23. Del Poeta G, Venditti A, Del Principe MI et al (2003) Amount of spontaneous apoptosis detected by $\mathrm{Bax} / \mathrm{Bcl}-2$ ratio predicts outcome in acute myeloid leukemia (AML). Blood 101:2125-2131

24. Dlugosz PJ, Billen LP, Annis MG et al (2006) Bcl-2 changes conformation to inhibit Bax oligomer izat ion. EMBO J 25:22872296

25. Sedletska Y, Giraud-Panis MJ, Malinge JM (2005) Cisplatin is a DNA damaging antitumour compound triggering multifactorial biochemical responses in cancer cells: importance of apoptotic pathways. Curr Med Chem Anticancer Agents 5:251-265

26. Ryningen A, Ersvaer E, Oyan AM et al (2006) Stress-induced in vitro apoptosis of native human acute myelogenous leukemia (AML) cells shows a wide variation between patients and is associated with low BCL-2:Bax ratio and low levels of heat shock protein 70 and 90. Leuk Res 30:1531-1540

27. Riedl SJ, Shi Y (2004) Molecular mechanisms of caspase regulation during apoptosis. Nat Rev Mol Cell Biol 5:897-907

28. Nuñeza G, Benedict MA, Hu Y, Inohara N (1998) Caspases: the proteases of the apoptotic pathway. Oncogene 17:3237-3245

29. Fan T, Han L, Cong R, Liang J (2005) Caspase family proteases and apoptosis. Acta Biochim Biophys Sin 37:719-727

30. Zhang XD, Nguyen T, Thomas WD, Sanders JE, Hersey P (2000) Mechanisms of resistance of normal cells to TRAIL induced apoptosis vary between different cell types. FEBS Lett 482: 193-199

31. Dejosez M, Ramp U, Mahotka C et al (2000) Sensitivity to TRAIL/APO-2L-mediated apoptosis in human renal cell carcinomas and its enhancement by topotecan. Cell Death Differ 7:1127-1136

32. Srivastava RK (2001) TRAIL/Apo-2L: mechanisms and clinical applications in cancer. Neoplasia 3:535-546

33. Pan G, O'Rourke K, Chinnaiyan AM et al (1997) The receptor for the cytotoxic ligand TRAIL. Science 276:111-113

34. Pan G, Ni J, Wei YF, Yu G, Gentz R, Dixit VM (1997) An antagonist decoy receptor and a death domain-containing receptor for TRAIL. Science 277:815-818

35. Ashkenazi A, Dixit VM (1999) Apoptosis control by death and decoy receptors. Curr Opin Cell Biol 11:255-260

36. Lavrik I, Golks A, Krammer PH (2005) Death receptor signaling. J Cell Sci 118:265-267

37. Wajant H (2003) Death receptors. Essays Biochem 39:53-71

38. Brenner C, Kroemer G (2000) Apoptosis: mitochondria-the death signal integrators. Science 289:1150-1151 